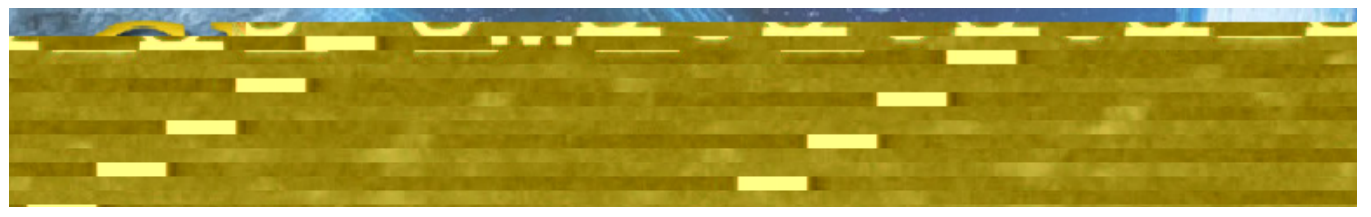

\title{
DNA extraction from skins of wild (Hydrochoerus hydrochaeris and Pecari tajacu) and domestic (Sus scrofa domestica) species using a novel protocol
}

\author{
G.N. Ojeda ${ }^{1}$, P.S. Amavet ${ }^{1,2,3}$, E.C. Rueda ${ }^{1}$ and P.A. Siroski ${ }^{3,4}$ \\ ${ }^{1}$ Departamento de Ciências Naturales, Facultad de Humanidades y Ciências, \\ Universidad National del Litoral, Santa Fe, Argentina \\ ${ }^{2}$ Consejo National de Investigaciones Científicas y Técnicas, Buenos Aires, \\ Argentina \\ ${ }^{3}$ Laboratorio de Zoología Aplicada: Anexo Vertebrados, Santa Fe, Argentina \\ ${ }^{4}$ Secretaria de Medioambiente, Santa Fe, Argentina \\ Corresponding author: G.N. Ojeda \\ E-mail: g.ojedaschulte@gmail.com
}

Genet. Mol. Res. 11 (1): 672-678 (2012)

Received February 3, 2011

Accepted November 29, 2011

Published March 19, 2012

DOI http://dx.doi.org/10.4238/2012.March.19.1

\begin{abstract}
Sometimes, commercial products obtained from wild animals are sold as if they were from domestic animals and vice versa. At this point of the productive chain, legal control of possible wildlife products is difficult. Common in the commerce of northern Argentina, skins of two wild species, the carpincho and the collared peccary, look very similar to each other and to those of the domestic pig; it is extremely difficult to differentiate them after they have been tanned. Because there was no an adequate methodology to discriminate between leather of these three species, we developed a new methodology of DNA extraction from skin and leather. This new method involves digesting a leather sample using proteinase $\mathrm{K}$, followed by precipitation of proteins with $5 \mathrm{M} \mathrm{NaCl}$, cleaning with absolute isopropanol and DNA precipitation with $70 \%$ ethanol. DNA is hydrated in Tris-EDTA buffer. This protocol provided good-quality DNA suitable for analysis with molecular markers. This new protocol has potential for use in
\end{abstract}


identifying leather products of these species using molecular markers based on RAPDs.

Key words: DNA isolation; Animal skins; Leather

\section{INTRODUCTION}

In the northern region of Argentina, some wild and domestic species share geographic distribution and features related to skin and meat: carpincho or capybara (Hydrochoerus hydrochaeris), collared peccary (Pecari tajacu) and domestic pig (Sus scrofa domestica). For this reason, all of them are exploited commercially by different ways and conditions. The carpincho is the largest rodent in the world and belongs to the family Caviidae. It is a South American endemic herbivorous amphibian locally common and widespread, and shows a strong social behavior. When it becomes an adult, it can weigh as much as $55 \mathrm{~kg}$. The collared peccary is an omnivorous mammal, and it has a broad distribution from United Stated to Argentina (Albert et al., 2004). It belongs to family Tayassuidae and suborder Suiformes (Groves and Grubb, 1993). These species have a close taxonomic relationship with the domestic pig (family Suidae). The domestic pig is an introduced species in Argentina, which is raised for commercial purposes such as domestic livestock in most of the provinces.

The autochthonous species, collared peccary and carpincho are included in the same category in the Red List of Threatened Species as least concern, but the population trends are different and they are reported as stable and unknown, respectively (IUCN, 2010). In CITES (Convention on International Trade in Endangered Species of Wild Fauna and Flora) there are lists of species afforded different levels or types of protection from over-exploitation. The collared peccary is listed in Appendix II, where there is a list of species that are not necessarily threatened with extinction now but may become so unless trade is closely controlled. The carpincho is not included in any appendix.

Since 1981, in Argentina, both species are protected by the National Law No. 22421 that rules on the use and conservation of the wildlife species, and they are considered as potentially vulnerable (Diaz and Ojeda, 2000; Chebez, 2008). Later, the Resolution No. 793/87 of the ex Secretaría de Agricultura, Ganadería y Pesca de la Nación passed prohibiting the export, trafficking and marketing among provinces of products and by-products of collared peccary. Despite this ban, in some provinces, collared peccary hunting is allowed only for trophy purposes. Each province has its own laws involving aspects such us the use and conservation of regional species. Carpincho hunting is prohibited (Provincial Law No. 4830) in Santa Fe Province but not in Formosa, Chaco and Corrientes Provinces. In these cases, when some species cover many provinces as a home range, to apply control mechanisms is much more complicated because there is a lack of one common legislation for the use of the wildlife. However, in Argentina, there is a national carpincho management program mostly related to hunting techniques.

The trade in products of the carpincho and collared peccary is also found all around the country, but for the latter, this is not legally permitted. Frequently, carpincho skins from provinces where hunting is not allowed appear on the market. Basically, commercial products that are made with these wild species parts are permitted depending on where those animals were obtained.

One particular characteristic concerning carpincho, collared peccary and domestic pig is that after tanning, the skins look very similar, and it is extremely difficult to differentiate them. Therefore, it can often be found that commercially available products obtained from the 
leather of these wild animals are sold as if they were from domestic animals, and vice versa. In both cases, this is an illegal and inapropiate use of wildlife. For this reason, the control of these products is very hard in order to prevent trafficking of wildlife.

Nowadays, there is no appropriate method to enable an efficient way to discriminate between leather from carpincho, peccary and domestic pig. The development of a fast and effective system to identify these products is essential for the control of illegal trade of our wildlife. Molecular biology techniques provide useful tools for rapid analysis and specific identification. Molecular markers based on DNA sequence (such us random amplified polymorphic DNA or RAPD) have been widely used to study genetic variation and population structure in these species, whose genomes have not been well characterized (Welsh and McClelland, 1990; Amavet et al., 2007, 2009). The application of these methods would help to discriminate between different genomes, taking into account that their skins are frequently indistinguishable along the marketing chain.

The goal of this study was to provide a protocol for DNA extraction from skins and leather, applying a method that allows non-invasive sampling directly using the marketed (commercially available) product and also proposes a rapid, inexpensive and efficient method to determine the leather origin using molecular markers.

\section{MATERIAL AND METHODS}

Skin fragments were collected from of three specimens of each species. The samples were obtained after some complaints and confiscation of products, as part of the activities of the National Program for Conservation and Management of Carpincho or from local inhabitants of Santa Fe and Formosa Provinces. Samples were taken from tanned, dry, fresh, or salted hide, representing different methods of skin conservation.

Once collected, samples of the hides were washed with tap and distilled water and dried at $40^{\circ} \mathrm{C}$. The samples were then kept at $-20^{\circ} \mathrm{C}$ until processing.

\section{DNA extraction}

For DNA extraction, we used the Sambrook et al. (1989) protocol with some modifications in order to obtain a good amount of DNA. A small tissue sample of $25 \mathrm{mg}$ was placed in a $1.5-\mathrm{mL}$ tube. Next, $500 \mu \mathrm{L}$ lysis buffer $(50 \mathrm{mM}$ Tris-HCl, $\mathrm{pH} 8.0,50 \mathrm{mM}$ EDTA, $1 \%$ SDS, and $50 \mathrm{mM} \mathrm{NaCl})$ and $5 \mu \mathrm{L}$ proteinase $\mathrm{K}\left(20.1 \mathrm{mg} / \mu \mathrm{L}\right.$, Fermentas $\left.{ }^{\circledR}\right)$ were added and the samples incubated at $55^{\circ} \mathrm{C}$ in a water bath for $8 \mathrm{~h}$ with stirring. The samples were then centrifuged for $20 \mathrm{~min}$ at 13,000 rpm, and $500 \mu \mathrm{L}$ was removed from the supernatant (avoiding the pellet as well as the superficial oily layer if any) and placed in a new tube. Afterwards, $300 \mu \mathrm{L}$ $5 \mathrm{M} \mathrm{NaCl}$ was added and the samples centrifuged for $15 \mathrm{~min}$ at 13,000 rpm. Finally, $500 \mu \mathrm{L}$ of the supernatant was recovered and DNA precipitated by the addition of an equal volume of absolute isopropanol. Samples were shaken briefly, and then thoroughly vortexed. The tubes were then centrifuged at 13,000 rpm for $15 \mathrm{~min}$, discarding the liquid with care not to disturb the pellet. The pellet was washed with $750 \mu \mathrm{L} 70 \%$ ethanol and centrifuged for $5 \mathrm{~min}$ at 13,000 $\mathrm{rpm}$ to remove the alcohol. DNA was dissolved in $25 \mu \mathrm{L} 1 \mathrm{X}$ TE buffer.

To determine the quality and concentration of DNA obtained, the samples were electrophoresed on a $0.8 \%$ agarose gel in $0.5 \mathrm{X}$ TBE and DNA quantified with a UV spectrophotometer (Amersham Pharmacia). 


\section{Amplif cation of polymorphic regions using RAPD primers by the polymerase chain reaction $(\mathrm{PCR})$}

Amplification reactions were carried out according to the method of Lage et al. (2008) in a final volume of $25 \mu \mathrm{L}$, containing $10 \mathrm{mM}$ Tris- $\mathrm{HCl}, \mathrm{pH} 8.3,50 \mathrm{mM} \mathrm{KCl}, 2 \mathrm{mM} \mathrm{MgCl}{ }_{2}$, $0.01 \%$ gelatin, $200 \mathrm{pM}$ dATP, dTTP, dGTP and dCTP, 5 pM selected primer, $1.25 \mathrm{U}$ Taq DNA polymerase, and $25 \mathrm{ng}$ genomic DNA. Amplification reactions were performed in an $\mathrm{MPI}^{\circledR}$ thermal cycler with a program of 45 iterative cycles of $1 \mathrm{~min}$ at $94^{\circ} \mathrm{C}, 1 \mathrm{~min}$ at $36^{\circ} \mathrm{C}$ and $2 \mathrm{~min}$ at $72^{\circ} \mathrm{C}$, with an initial denaturation of $4 \mathrm{~min}$ at $94^{\circ} \mathrm{C}$ and a final extension at $72^{\circ} \mathrm{C}$ for $7 \mathrm{~min}$.

A set of 20 random 10-mer primers from Promega ${ }^{\circledR}$ (B050-10 and B051-10) were tested. Each sample was amplified with each primer at least twice to ensure reproducibility of banding patterns. To avoid contamination of PCR experiments, all the necessary precautions were taken; in particular, the procedures of pre- and post-amplification aliquots were separated and fresh reagents for each experiment were used whenever possible. To test the reliability of the PCR products, controls with no genomic DNA were used routinely.

\section{Analysis of amplif ed products}

PCR products were analyzed by electrophoresis on a $2 \%$ agarose gel stained with Gel

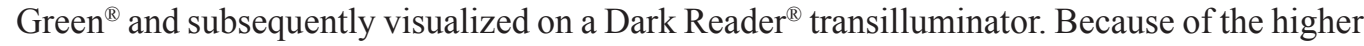
definition, we analyzed PCR products by electrophoresis on $4 \%$ polyacrylamide gels of $33 \mathrm{~cm}$ x $39 \mathrm{~cm}$, at $2200 \mathrm{~V}$ and $75 \mathrm{~W}$ in $0.5 \mathrm{X}$ TBE buffer, stained with silver nitrate solution (Bassam et al., 1991). Stained gels were photographed with a digital camera (Olympus C5000) using the macro mode.

\section{RESULTS}

This study applied the DNA extraction protocol with $5 \mathrm{M} \mathrm{NaCl}$ in combination with proteinase $\mathrm{K}$ digestion to the analysis of skin samples (leather) obtained by a non-invasive method. This technique was successful in extracting DNA in an adequate quantity as well as moderate purity, necessary conditions for RAPD-PCR analysis (Figure 1).

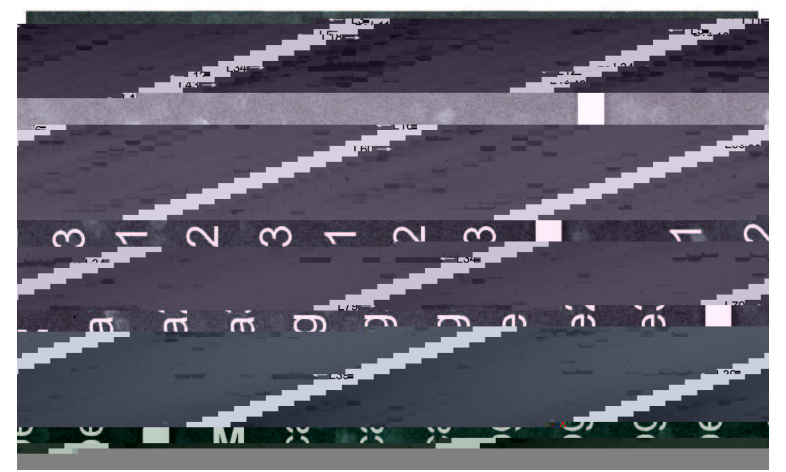

Figure 1. DNA quantification for 9 samples. Lane $M=$ a molecular weight marker (100 ng/ $\mu \mathrm{L})$; lanes ca1, ca2 and $c a 3=$ carpincho samples; lanes pg1,pg2 and pg $3=$ pig samples; lanes pe1, pe 2 and pe $3=$ peccary samples. 
Primers tested were 10 of the A series and 10 of the B series (Promega ${ }^{\circledR}$ ), and we selected the seven that showed the best resolution and reproducible bands, as well as being sufficiently polymorphic. The primers chosen for the specific analysis were A1, A2, A3, A5, B1, B2, and B6 (Table 1).

Table 1. Selected primers for amplifying all samples.

\begin{tabular}{ll}
\hline Primer & Sequence $\left(5^{\prime} \rightarrow 3^{\prime}\right)$ \\
\hline A1 & CCC AAG GTC C \\
A2 & GGT GCG GGA A \\
A3 & AAG ACC CCT C \\
A5 & CAC CAG GTG A \\
B1 & TCG AAG TCC T \\
B2 & GCA TGT CAG A \\
B6 & GTG ACA TGC C \\
\hline
\end{tabular}

These primers were informative for specific differentiation, because they revealed an adequate number of polymorphic bands between these entities. We studied between 39 and 89 polymorphic bands per primer, and we analyzed a total of 345 polymorphic loci. The analysis system used allowed us to recognize the DNA belonging to different species, proving to be an applicable method for the control of commercial products of these species of native fauna (Figure 2).

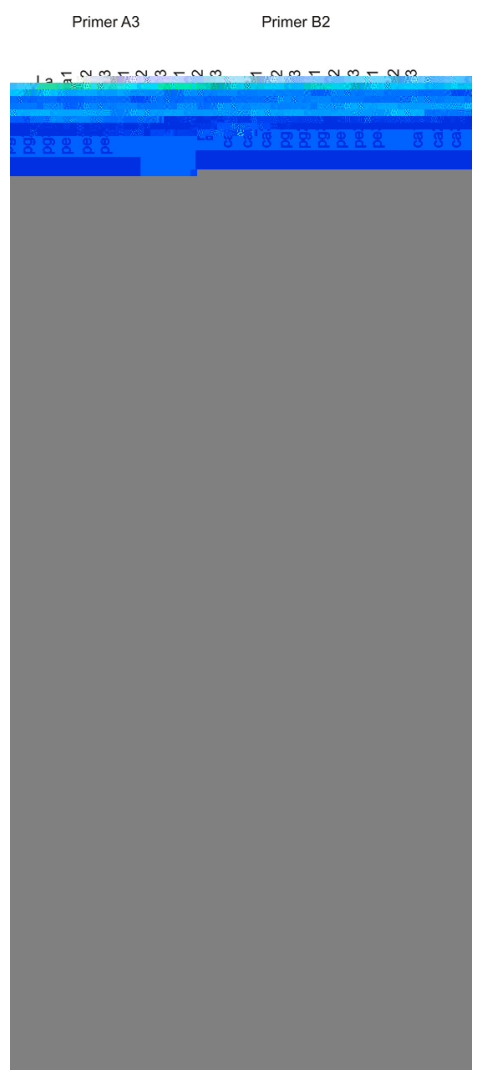

Figure 2. Polyacrylamide gel (4\%). Samples amplified using primers A3 and B2. Lane $M=$ molecular marker; lanes ca1, ca2, ca3 = carpincho samples; lanes pg1, pg2, pg3 = pig samples; lanes pe1, pe2, pe3 = peccary samples. 
This study allowed us to analyze loci exclusive to each species, with the following results: 57 exclusive loci for H. hydrochaeris, 104 loci for S. s. domestic and 62 loci for P. tajacu. We also note that there are differences within species. We observed 156 polymorphic loci in $H$. hydrochaeris, which showed a greater polymorphism, 110 polymorphic loci in $P$. tajacu and finally 47 polymorphic loci in S. s. domestica. Thus, the domestic pig is the species with least variation observed in this study (Table 2). The primers A2 and A3 showed the best results and, indeed, are the most informative regarding the differentiation of the species.

\begin{tabular}{|c|c|c|c|c|c|c|}
\hline \multirow[t]{2}{*}{ Primer } & \multicolumn{3}{|c|}{ Exclusive loci } & \multicolumn{3}{|c|}{ Polymorphic loci } \\
\hline & H. hydrochaeris & P. tајаси & S. s. domestica & H. hydrochaeris & P. tajacu & S. s. domestica \\
\hline A1 & 6 & 9 & 15 & 19 & 17 & 8 \\
\hline A2 & 10 & 10 & 20 & 17 & 8 & 6 \\
\hline A3 & 27 & 13 & 10 & 38 & 36 & 8 \\
\hline A5 & 3 & 10 & 29 & 19 & 5 & 0 \\
\hline B1 & 2 & 5 & 8 & 22 & 13 & 14 \\
\hline B2 & 4 & 9 & 3 & 17 & 16 & 7 \\
\hline B6 & 5 & 6 & 19 & 24 & 15 & 4 \\
\hline
\end{tabular}

\section{DISCUSSION}

This report introduces a novel DNA extraction protocol for leather samples, tissue rarely used for this purpose. The use of this tissue for sampling has the advantage of not needing to carry awkward materials or tools to the sampling site, where the animals are not subjected to stressful situations and where the skin samples do not need to be transported at low temperature. Also, we achieved successful DNA tests for hides in various states of preservation such as raw hides, skins and hides dry salted. The advantages make this technique a fast, economical and very effective method for DNA extraction. In fact, we did not find reports of any previous study that considered DNA extraction from mammalian leather; similar protocols for DNA extraction have been implemented only in forensic research in humans (White and Densmore, 1992).

We carried out many assays applying the standard phenol-chloroform DNA extraction protocol and even with commercially available DNA extraction kits, but no successful results were obtained. In the phenol-chloroform procedure, the DNA obtained was degraded. With the use of DNA extraction kits, we obtained very low DNA amounts. In both cases, PCR was very difficult to optimize because of the variation in DNA quality.

The classic methodologies applied to distinguish different species involve taxonomic studies based on morphological traits (Crisci and Armengol, 1983). Molecular biology techniques based on DNA have the advantage of being rapid and effective in the analysis of genetic variability in species and populations (Avise, 1994). This report shows that RAPD markers are a suitable tool for the identification of species, providing relevant banding patterns exclusive to each of them. In addition, these markers may be used in future studies of genetic variation within and between populations for each of these species, a subject which has no history in Argentina and is very important to clarify the geographic origin of the skins. 
This study describes a non-invasive sampling method beside the novel method of DNA extraction, which can be useful for genetic studies of endangered wild species with dwindling numbers, such as those whose population status is uncertain.

Based on our results, we propose a new method that can be used to discriminate hides between these three species, which contributes to ecological studies, as well as to combating illegal hunting of carpinchos and peccaries, the illegal sale of their products and fraudulent marketing.

\section{ACKNOWLEDGMENTS}

Research supported by Secretaría de Ciencia, Tecnología e Innovación of Santa Fe Province, Argentina. We would like to thank María Luisa Bolkovic of the Dirección de Fauna Silvestre, Secretaría de Ambiente y Desarrollo Sustentable of Argentina, Ayelén Eberhardt and the Dirección General de Manejo Sustentable de Fauna y Flora (M.A.S.P. y M.A. of the Province of Santa Fe) for their assistance in providing samples. P.S. Amavet is a member of Carrera del Investigador Científico, Consejo Nacional de Investigaciones Científicas y Técnicas (CONICET), Argentina.

\section{REFERENCES}

Albert S, Ramotnik CA and Schmitt CG (2004). Collared peccary range expansion in northwestern New Mexico. SW Nat. 49: 524-528.

Amavet PS, Rosso EL, Markariani RM and Larriera A (2007). Analysis of the population structure of broad-snouted Caiman (Caiman latirostris) in Santa Fe, Argentina, using the RAPD technique. J. Herpetol. 41: 294-300.

Amavet P, Vilardi JC, Rosso E and Saidman B (2009). Genetic and morphometric variability in Caiman latirostris (broadsnouted caiman), Reptilia, Alligatoridae. J. Exp. Zool. A Ecol. Genet. Physiol. 311: 258-269.

Avise JC (1994). Molecular Markers, Natural History and Evolution. Chapman \& Hall, New York.

Bassam BJ, Caetano-Anolles G and Gresshoff PM (1991). Fast and sensitive silver staining of DNA in polyacrylamide gels. Anal. Biochem. 196: 80-83.

Chebez JC (2008). Los que Se Van. Fauna Argentina Amenzada. Ed. Albatros, Buenos Aires.

Crisci JV and Armengol MFL (1983). Introducción a la Teoría y Práctica de la Taxonomía Numérica. Serie Biología. Monografía No. 26. O.E.A., Washington.

Diaz GB and Ojeda RA (2000). Libro Rojo de Mamíferos Amenazados de la Argentina. SAREM, Mendoza.

Groves CP and Grubb P (1993). The Suborder Suiformes. In: Pigs, Peccaries and Hippos IUCN (Oliver WLR, ed.). The World Conservation Union, Gland, 1-4.

IUCN (2010). IUCN Red List of Threatened Species. Version 2010.4. Available at [www.iucnredlist.org]. Accessed December 2010.

Lage EAS, Telles MPC, Soares TN, Resende LV, et al. (2008). Variabilidade genética em bandos de queixada (Tayassu pecari) do Parque Nacional das Emas utilizando marcadores RAPD (random amplified polymorphic DNA). Neotrop. Biol. Conservat. 3: 126-134.

Sambrook J, Fritsch EF and Maniatis T (1989). Molecular Cloning: A Laboratory Manual. 2nd edn. Cold Spring Harbor Laboratory Press, Cold Spring Harbor, New York.

Welsh J and McClelland M (1990). Fingerprinting genomes using PCR with arbitrary primers. Nucleic Acids Res. 18: 7213-7218.

White PS and Densmore LD (1992). Mitochondrial DNA Isolation. In: Molecular Genetic Analysis of Populations. A Practical Approach. The Practical Approach Series (Hoelzel AR, ed.). IRL Press at Oxford University Press, Oxford, 29-57. 